\title{
SECTION 2-302 OF THE UNIFORM COMMERCIAL CODE: THE CONSEQUENCES OF UNCONSCIONABILITY IN SALES CONTRACTS
}

EQUTTY has traditionally required that a contract be fair in all its parts before specific performance will be granted. ${ }^{1}$ The degree of unconscionability necessary to bar relief is unclear, ${ }^{2}$ although an improvident bargain is ordinarily no defense. ${ }^{3}$ But courts have generally been unwilling to recognize

1. Texas Co. v. Andres, 97 F. Supp. 454 (N.D. Idaho 1951) ; Bowen v. Waters, 3 Fed. Cas. 1058, No. 1725 (S.D.N.Y. 1827) ; Cowen v. McNealy, 342 Ill. App. 179, 96 N.E.2d 100 (1950) ; Pomeroy, Specific Performance of Contracts $\$ 40$ (3d ed. 1926) (hereinafter cited as Poneroy). Specific performance is a discretionary remedy. Pope Mfg. Co. v. Gormully, 144 U.S. 224, 236 (1892) ; Seymour v. Delancy, 3 Cow. 445, 505 (N.Y. 1824); dE Funiak, HANdBook of Modern EQuity \$91 (1950). In deciding whether a contract is fair, courts look to surrounding circumstances as well as to the contract itself. See Grieson v. Winey, 240 Fed. 691, 692 (8th Cir. 1917) ; Panco v. Rogers, 19 N.J. Super. 12, 18, 87 A.2d 770, 773 (Ch. 1952); Poneroy $\$ 183$. There is a conflict of opinion as to whether circumstances subsequent to the actual negotiation will be considered in determining fairness. Id. \$177. Even courts which profess to look only at events occurring at the time the contract was made may actually consider subsequent events by invoking the equitable doctrine that a contract will not be specifically enforced if it will work a hardship on either party. Id. $\$ 185$; Comment, 18 U. of CHr. L. REv. 146, 149-50 (1950).

2. Since specific performance is discretionary with the court and each case is decided on its own particular facts, no adequate standards have been estallished. 1 PAGE, CONTRACTS $\$ 641$ (2d ed. 1920) (hereinafter cited as PAGE). Specific performance has been denied on numerous and widely varying grounds. See, e.g., Campbell Soup Co. v. Wentz, 172 F.2d 80 (3d Cir. 1948) (specific performance refused because of one unfair clause) ; Texas Co. v. Andres, 97 F. Supp. 454 (N.D. Idaho 1951) (refusal to enforce "option to buy" clause in lease because defendant did not realize its meaning); Grieson v. Wincy, 240 Fed. 691 (8th Cir. 1917) (fraud); Rust v. Conrad, 47 Mich. 449, 11 N.W. 265 (1882) (lack of mutuality) ; McElroy v. Maxwell, 101 Mo. 294, 14 S.W. 1 (1890) (concealment of material facts in negotiation). The vague nature of the standard is increased because there has never been an adequate definition of an "unconscionable contract." The standard definition was originated by Lord Hardwicke in Earl of Chesterfield v. Janssen, 2 Ves. Sen. 125, 155, 28 Eng. Rep. 82, 100 (1750): An unconscionable bargain is one "such as no man in his senses, and not under delusion would make on the one hand, and as no honest and fair man would accept on the other. ..." Similar definitions are nitmerous. See, e.g., Hall v. Wingate, 159 Ga. 630, 667, 126 S.E. 796, 813 (1924) ; Franklin Fire Insurance Co. v. Noll, 115 Ind. App. 289, 294, 58 N.E.2d 947, 949 (1945). See PAGE $\$ 641$. Page and Pomeroy enumerate several characteristics of an unconscionable bargain. PaGe \$641.; PoMeroy \$ 40.

3. Arentsen v. Sherman Tawel Service Corp., 352 Ill. 327, 185 N.E. 822 (1933); Knott v. Cutler, 224 N.C. 427, 31 S.E.2d 359 (1944). See DE Funisk, op. cit. supra note 1, §92. Contra: Stone v. Pratt, 25 Ill. 25 (1860). Several state statutes provide that inadequacy of consideration alone is enough to preclude specific performance. See, e.g., Cal. Civil Code §3391(1) (Deering, 1949); GA. Code ANn. \$37-805 (1936); Mont. REv. Code § 17-808(1) (1947) ; N.D. Rev. Code § 32-0413(1) (1943). 
unfairness as a ground for recission and cancellation, action for damages. ${ }^{\overline{3}}$ However, by finding fraud, lack of mutuality, or ambiguity, courts have often refused to award damages on an unconscionable contract. ${ }^{6}$

Section 2-302 of the Uniform Commercial Code 7 makes unconscionability a defense ${ }^{8}$ to all actions, legal or equitable, ${ }^{9}$ based on sales contracts. But

4. A dichotomy between specific performance and cancellation has long been recognized. See Cathcart v. Rabinson, 5 Pet. 264, 275 (U.S. 1831); Thompson v. Jacksson, 24 Va. 504, 505 (1825). See 5 Conein, Contricts $\$ 1136$ (1951). Thus, the courts have frequently noted that a refusal of specific performance does not autumatically entitle the defendant to cancellation. Hepburn v. Dunlup, 1 Wheat. 179 (U.S. 1816); Panco v. Rogers, 19 N.J. Super. 12, 87 A.2d 770 (Ch. 1952); Newman v. Kay, 57 W. Va. 98, 49 S.E. 926. See 3 Eliotr, CoNtricts $\$ 2411$ (1913). When the court refuses both to enforce specifically and to cancel, the plaintiff is leit to his remedy "at law." Sce Pope Mfg. Co. v. Gormully, 144 U.S. 224, 236 (1892) : Van Norsdall v. Smith, 141 Mich. 355, 362,104 N.W. 660,662 (1905) : Clay v. Landreth, 187 Va. 169, 179, 45 S.E.2d 875, 881 (1948).

5. 1 Corbin, Contracts $\$ 12 \$$ (1950). Contra: Hume v. United States, 132 U.S. 400 (1899) : Work v. Fidelity Oil \& Gas Co., 79 Kan. 118, 98 Pac. 801 (1908).

6. Weil v. Chicago Pneumatic Trol Co., 138 Ark. 534, 212 S.W. 313 (1919) (hack of mutuality) : Hardy v. General Motors Acceptance Corp., 38 Ga. App. 463, 144 S.E. 327 (192S) (vagueness and ambiguity); Planters Nat. Bank of Fredericlishurg v. E. G. Hefin Co., 166 Va. 166, 1S4 S.E. 216 (1936) (constructive fraud). Another methou used by common law courts to olitain the desired result was through tortured interpretation of the contract terms. See New Prague Flouring Mill Co. v. Spears, 194 Iowa 417, 189 N.WW. 815 (1922) : Bekkevold v. Potts, 173 Minn. 87, 216 N.W. 790 (1927). For a full diseussion of the methuds used by courts to avoid unfair contracts, see Notes, 58 YALE L.J. 1161 (1949) ; 27 CoL. L. Rev. 178 (1927).

7. This section is new to the law. It did not appear in the Uniform Sales Act, the predecessor to Article Two of the present Code Unifors Cosmencral Cone $\$ 2-302$, Comment (Official Draft 1952) (hereinafter cited as UCC). The Section states: "1) If the court finds the contract or any clause of the contract to be unconscionable it may refuse to enforce the contract or may strike any unconscionable clause and enforce the contract as if the stricken clause had never existed. 2) When it is claimed or appears to the court that the contract or any clause thereof may be unconscionable the court may afford the parties an opportunity to present evidence as to its commercial setting, purpose and effect to aid the court in making the determination." ICC $\$ 2-302$ (Official Urait, 1952). The section was discussed before its final enactment in 18 U. of Cur. L. REv. 146 (1950).

The Code has been introduced and is now under legislative study in California, Connecticut, Illinois, Indiana, Massachusetts, New Hampshire, New York, Ohio, Oliahuma, Oregon, Rhode Island, and Wisconsin. It has already been enacted in Pennsylvania and becomes effective there on July 1, 1954. 7 Conference on Persosin. Finasice Law QUARTERIY REPORT 72-6 (Summer 1953).

8. The section was apparently designed to apply unly as a defense since the wurds "refuse to enforce" are used. However, it is quite possible that it might be utilized affirnatively in an action for reformation. Plaintiff in such an action could argus that the court in reforming the instrument should heed the command of the scetion and "refuse to eniorce" any unconscionable clauses in their fashioning of the reformed instrument. Historically, reformation was only decreed to cunfurm an agreement to fit the actual in. 
if only part of a contract is unconscionable, that part may be stricken and the remainder enforced. The section further provides that whenever "it is claimed or appears" that the contract is unconscionable, the parties may "present evidence as to its commercial setting, purpose and effect." These provisions were designed to promote explicit judicial policing of contract terms ${ }^{10}$ without resort to strained interpretations of traditional contract doctrines. ${ }^{11}$

For historical reasons, some courts may have difficulty in adjusting to their new role ${ }^{12}$ under Section 2-302. This difficulty will be particularly acute in actions on non-separable contracts, since literal application of the section will require complete denial of relief-in effect, the cancellation of the instrument. ${ }^{10}$ Courts well-versed in the traditional equity dichotomy between specific performance and cancellation may be reluctant. to cancel the contract even though unwilling to decree specific performance. ${ }^{14}$ As a compromise between full enforcement and complete denial of relief, these courts may be persuaded to substitute fair terms for unconscionable ones and enforce the contract as rewritten.

tent of the parties when this intent had been frustrated by a mistake of fact or law. Scc Philippine Sugar Co. v. Philippine Islands, 247 U.S. 385, 389 (1918). However, $\$ 2-302$ could be construed to mean that unconscionability shall now become a ground for reformation, in that unconscionability connotes that a substantive error has been made by one of the parties. Any court seeking buttress for such an argument could find it in the usc of the terms "reformed" and "reformation" in prior drafts of the section. See UCC $\S 2-302$, Comment (Tentative Draft, 1949); Uniform Revised SAles Act $\$ 23$ (Proposed Final Draft No. 1, 1944).

9. 18 U. of CHI. L. REv. 146, 150 (1950); cases cited in UCC $\$ 2-302$, Comment (Official Draft, 1952) as motivating the enactment of the section are of both a legal and equitable nature. The drafters once contemplated rephrasing the words "refuse to enforce" to avoid the inference that the section is meant to deal only with questions of specific performance. UCC, Revisions to Proposed Final Draft No. 2 (May, 1951). This proposal was not carried through. Nonetheless, since the drafters clid not indicate otherwise, the section must be presumed to extend to all actions, regarclless of the nature of the relief sought.

10. "This section is intended to make it possible for the courts to police explicitly against the contracts or clauses which they find to be unconscionable." UCC $\$ 2-302$, Comment (Official Draft, 1952).

11. See note 6 supra; UCC $\$ 2-302$, Comment (Official Draft, 1952).

12. That the section is new to sales law is not open to doubt. Culifonnis Annotstions to Proposed Uniporm Commercial Code \$2-302 (1952) ; Report on the Proposed Uniform Commercial Code 18 (New York City Bar Association, 1952) ; Pennsylvania Annotations to the Proposed Uniform Commercial Code 8, 18 (1952); 17 Aluany L. Rev. 11, 22 (1952); Comment, The Uniform Commercial Code-The Effect of its Adoption in Tennessee, 22 TenN. L. Rev. 776, 793 (1953).

13. The section allows only a refusal to enforce or a striking of unconscionable terms and the enforcement of the rest of the contract. See note 7 supra. Obviously, if the contract is non-separable the "strike and enforce" part of the Section is meaningless. Thus, the court has only two alternatives when faced with a non-separable contract-enforcement or a refusal to enforce.

14. See cases cited note 4 supra. 
Substitution as a technique is open to grave doubt. In a damage action it would require assessment of damages based on the substituted clauses. Thus the defendant would be required to pay damages for breach of a contract which he never had an opportunity to perform. Had the substituted clauses been available to him from the outset, the defendant might not have breached the agreement. While this objection does not apply to suits for specific performance, there are others which do. Substitution, if extended beyond price or other equally definite provisions, might lead the court into a morass of conflicting and often intangible evidence. Thus, formulation of the precise terms of a fair contract would depend on arbitrary judicial concepts of fairness. ${ }^{15}$ The results of such judicial speculation might be a contract quite at variance with the intention of either or both of the parties. When enforcement of a contract, either by damages or specific performance, is refused. it is difficult to see why any substitution should be imposed.16 Moreover, to the extent that the purpose of the section is to deter the drafting uf unconscionable contracts, ${ }^{17}$ substitution conflicts with it. The punishment imposed upon the drafter would be far less severe in nost situations if substitution were allowed than if the entire contract were held roid. ${ }^{18}$

15. See 18 U. of Chr. L. Rev. 146, 152 (1950).

16. There may be instances in which the defendant las accepted part or all of the plaintiff's performance before realizing the unconsciunable nature of the cusitract and under circumstances which prevent the return of the guvds delivered. In such a situatiug there is some authority for the proposition that the plaintiff should he cumpunsated for the fair value of his performance. Hume v. United States, 132 U.S. 106 (18S9) and casss therein cited. A fortiori this same ductrine shuuld apply where the deiendant has partl performed but refuses to complete performance unon discuvery of the unconscionalility.

Since the defendant may not realize the unconscionability until aiter he has taken $\because$ me action on the contract, the doctrine of "waiver" should hase no applization under the section. Any action that the defendant has taken should go to the question wi whether the contract was actually unconscionable rather than constituting a waiver of the defense. The defendant should always be permitted to raise the unconscionability defense, hut should be required to explain away any performance on his part.

17. The purpose of the section may not be to punish those who drait unconscionable contracts, but rather to mold fair agreements for the parties whenever possible.

18. This same argument has been advanced with reference to the practice of fashioning unreasonable restraint of trade contracts into fair agreements. See Note, 45 Husw. L. REv. 751 (1931) ; Mason v. Provident Clothing and Supply [1913] A.C. 724, wherein Lord Moulton said at 745 , "It would in my opinion be pessimi esempli ii, when an employer has exacted a covenant deliberately framed in unreasonably wide terms, the Cosurts were to come to his assistance and, by applying their ingenuity and lnowlcdge of the law, carve out of this void covenant the maximum of what he might validly have required ... the hardship imposed by the exaction of unreasunable correnants by employers wutd be greatly increased if they could continue the practice with the expeetation thast ... the Court would in the end enable them to obtain everything which they could have obtained by acting reasonably."

Of course, there could be cases in which the plaintiff would prefer complete terminatiun of contractual relations to a substituted contract. Such situations would gerhaps cecur most frequently when the court substituted a new price clause. One party might well prefer "no contract" to a contract with a price neither desired nur cuntemplated. 
Although there may be rare situations in which substitution is preferable to termination of the parties' contractual relationship. Section 2-302, as written, does not provide for such a solution. ${ }^{10}$ While substitution might be implied as the counterpart of the power to enforce partially a separable contract, ${ }^{20}$ a provision permitting substitution, which appeared in an earlier draft of the section, was expressly eliminated from the final draft. ${ }^{11}$ In view of their traditional reluctance to rewrite contract terms, ${ }^{22}$ courts in reading the section may well invoke the doctrine that statutes in clerogation of the common law are to be strictly construed. ${ }^{23}$ On this basis, courts could, with justification. refuse to read substitution into the section.

The substitution problem is less likely to arise when separable contracts are in dispute because the section extends the equity doctrine of partial en. forcement to unconscionable contracts. ${ }^{24}$ While equity courts have not generally enforced only parts of an unconscionable contract, ${ }^{25}$ they have always recognized the power to enforce partially an illegal contract which is sepa-

19. The section permits only the striking of unconscionable provisions and the entforcement of the contract "as if the stricken clause had never existed." UCC §2-302 (Official Draft, 1952).

20. It could be argued that the power to strike clauses and enforce the remainder of the contract was meant to apply to both separable and non-separable contracts. If this is true, substitution is a necessity, since if the contract is non-separable and certain parts of it are stricken, there would be nothing left to enforce unless provisions wore substituted.

21. UCC \& 2-302 (Proposed Final Draft, Spring 1950) provided: "If the court finds the contract or any clause of the contract to be unconscionable, it may refuse to enforce the contract or strike any clauses and enforce the rest of the contract or stibstitute for the stricken clause such provision as zeould be implied under this Article if the strickin clause had never existed." (Italics supplied). This language also appeared in two carlier drafts. The Code of Commercial Law, art. II, part II, $\$ 23$ (Tentative Draft, 1948) ; UCC $\$ 2-302$ (Tentative Draft, 1949). In 1950 the substitution part of the section was stricken without explanation. UCC \$2-302, Revision of ARticle 2, 4, AND ARTiCle 9 (September 1950). However, proponents of substitution might argue that since $\S 1$-102 (3) $(\mathrm{g})$ of the Code provides that "Prior drafts of text and comments may not be used to ascertain legislative intent" no inference should be drawn from the fact that the drafters struck this part of the section.

22. See Columbia Gas Construction Co. v. Holbrook, 81 F.2d 417, 419 (6th Cir. 1936) ; Brown v. Manufacturer's Trust Co., 278 N.Y. 317, 324, 16 N.E.2d 350, 352 (1938); Southern Style Shops, Inc. v. Mann, 157 Tenn. 1, 4, 4 S.W.2d 959 (1928).

23. See Scharfeld v. Richardson, 133 F.2d 340, 341 (D.C. Cir. 1943) ; State Bank of Milan v. Sylte, 162 Minn. 72, 75, 202 N.W. 70, 71 (1925).

24. The section makes it quite clear that the court may either refuse to enforce the entire agreement or may enforce only the fair parts. See note 7 supra.

25. 3 Elliotr, Contracts $\$ 2276$ (1913); 17 Albany L. Rev. 11, 22 (1952). A typical statement is that the contract must be fair in "all its parts" before any part of it will be enforced. See Soehnlein v. Pumphrey, 183 Md. 334, 337, 37 A.2d 843, 845 (1944); Clay v. Landreth, 187 Va. 169, 177, 45 S.E.2d 875,879 (1948). For an example of partial enforcement of an unconscionable contract see Nevada Nickel Syndicate, Ltd. v. National Nickel Co., 96 Fed. 133 (D. Nev. 1899). See also Rabinowitz v. Borish, 43 F. Supp. 413, 415 (D.N.J. 1942) ; Neely v. Broad Street Nat. Bank of Red Bank, 16 F. Supp. 839,840 (D.N.J. 1936). 
rable.26 Much of the litigation arising under the separability provision of Section 2-302 will concern form contracts. ${ }^{27}$ Many of these agreements are lengthy, couched in language that defies understanding, and printed in type of a size not conducive to careful reading. ${ }^{25}$ Form contracts generally reflect complete control of negotiations by the party drafting the instrument and almost total lack of bargaining power in the other party. ${ }^{20}$ Section 2-302 is designed to aroid exploitation of such situations by limiting the stronger party's ability to enforce the terms he dictates, thus forcing him to exercise restraint in drafting. ${ }^{3 n}$

Defining a separable contract may be a difficult problem in applying Section 2-302. The procrustean rule, that a clause is separable if a blue pencil can be run through it without rendering the remainder of the contract meaningless, 3

26. The doctrine originated in Figot's Case, 11 Co. Rep. 20b, 77 Eng. Kep. 1177 (1614). See also Osgood v. Bauder, 75 Iowa 550, 39 N.IY. \&87 (1883); 3 Wrususro:t, Sales $\$ 6 \$ 1$ (1948); Restatenievt, Covtracts $\$ \$ 605-07$ (1932); Comment, 33 Micn. L. REV. 278 (1934).

27. Indeed, when the Section was first promulgated as $\$ 23$ of the Lniform Revised Sales Act, the drafters were cuncerned sulely with form cuntract clauses. Crifores Rzvised SAlEs ACT $\$ 23$ (Propused Final Draft Xo. 1, 1944). Of course, as now written the section is not restricted to form contracts. It has even been suggested that its effect may extend bejond the law of sales. 1 Conbm, Contruts $\$ 133$ n.94 (1951).

28. See Note, $63 \mathrm{HARr}$. L. Rev. 494 (1950). For judicial recognition of these facts in the field of insurance law see DeLancey v. Insurance Co, 52 N.H. 581 (1873) where Judge Doe says at 587: "These provisions [of an insurance contract] were of such bulh and character that they would not he understourl ly men in general, even if suljiected to a careful and laborious study: by men in general, they were sure nut to be studied at all. . . The compound, if read by hin would, unless he were an extraurdinary man, be an inexplicable riddle, a mere fload of darkmess and confusion . .. it [the contract] was printed in such small type, and in lines so long and so crowded, that the perusal of it was made physically difficult, painful and injurious."

29. See Note, 63 Hanv. L. Rev. 494, 503 (1950). See also Note, 58 Yale L.J. 1161 (1949). For a complete discussion of standardized contracts see Prausarz, The Sra:inardization of Coursiegcial Contracts in ExGlish axd Conitumental Law (1937). See also, Kessler, Contracts of Adhesion-Some Thoughts About Freedom of Contrat, 43 CoL. L. Rev. 629 (1943) ; Radin, Contract Obligation and the Human Will, 43 CoL. L. REv. 575 (1943) ; Sales, Standard Form Contracts, 16 MIov. L. Rev. 318 (1953).

30. If companies utilizing form instruments have them overthrown by the courts they may simply "water down" the objectionable portion and hope that the next time the clause will be approved. Thus, the complete obliteration of undesirable clauses in a particular contract may not be accomplished in a single law suit.

Despite this expected influence of the section, some courts may still feel that by reiusing to enforce one form contract, they are endangering all such agrcements and encouraging mass breach against the company utilizing the instrument. Further, where the production process of an enterprise is dependent on the performance of their form instruments, this fear of mass breach becomes even more compelling. See Curtice Brothers v. Catts, 72 N.J. Eq. 831, 66 Atl. 935 (Ch. 1907) ; Friedburg, Inc v. MIcClary, 173 Ky. 579, 191 S.W. 300 (1917) ; Note, 58 YALE L.J. 1161, 1164 (1949).

31. Emler v. Ferne, 23 Ohio App. 218, 221, 155 N.E. 496, 497 (1926). 
is obviously figurative and mechanical. ${ }^{32}$ A more realistic approach would be to determine whether the unenforceable clause goes to the root of the bargain. The question is not whether the contract, in the abstract, is intelligible, but whether elimination of the unconscionable clause would so emasculate the contract that reasonable men, having the objectives of the parties, would not have drawn such an instrument. ${ }^{33}$ While the plaintiff cannot enforce an unconscionable contract, the defendant should not be allowed to ignore the contract when the unconscionable part does not corrupt the whole bargain. ${ }^{\text {g4 }}$

32. See Atwood v. Lamont, [1920] 3 K.B. 571, 578. See 32 ORE. L. Rev. 260, 262 (1953).

33. For a similar suggestion see Cumment, 33 MIrCH. L. Rev. 278, 284 (1934). Under the proposed test, if the purpose of the agreement can be effectuated without the unenforceable clause, the remainder of the contract should be enforced. But, if the unenforceable clause taints the entire agreement, no enforcement should be permitted. See Mason v. Provident Clothing and Supply Co., [1913] A.C. 724.

A hypothetical case may serve to illustrate the difference between the blue pencil test and the one here proposed. Suppose that $X$, a large and powerful oil company, made a gasoline dealership contract with $A$. By the terms of the contract, $A$ is to buy his gasoline only from $X$, and $80 \%$ of the profit of the gasoline station is to go to $X$. Further, $A$ is to handle only $X$ lubricants, honor $X$ credit cards and maintain his station in conformity with the company's general plan. In return $X$ is to construct the filling station. If the clause requiring $A$ to buy all his gasoline from $X$ and return $80 \%$ of the profits were found unconscionable, the "blue pencil test" would logically require its severence and the enforcement of the rest of the contract. However, if this contract is looked at careftully, it is clear that this clause is the very heart of the agreement and the rest of the contract, while intelligible, is of little practical significance. It is quite doubtful whether the contract would have been made without the objectionable clause. Thus, the court should refuse to enforce the entire bargain and relieve $A$ from the burden of performing the incidental clauses.

34. Such a policy might have led to a better result in Campbell Soup Co. v. Wentz, 172 F.2d 80 (3d Cir. 1949), noted in 58 Yale L.J. 1161 (1949). In that case Campbell had entered into a contract with George and Harry Wentz for the delivery of all of a certain type of carrot to be grown on the Wentz farm during 1947. Ey the time for delivery, the price had risen greatly. The Wentzes refused to deliver to Campbell and instead sold to a neighboring farmer who in turn sold some of the carrots to Campbell on the open market. Campbell sued to enjoin the further sale of carrots and to compel specific performance of the contract. The court considered several of the form clauses and found that they were not unconscionable standing alone. However, the court felt that one particular clause rendered the entire contract unconscionable. By this clause Campbell was excused from accepting carrots under certain circumstances. If and when such circumstances arose, the grower was not permitted to sell his carrots anywhere else unless Campbell agreed. The court expressly rejected the argument that this clause be separated from the rest of the contract saying, "The plaintiff argues that the provisions of the contract are separable. We agree that they are, but do not think that decisions separating out certain provisions from illegal contracts are in point here ... all we say is that the sum total of its provisions drives too hard a bargain for a court of conscience to assist." Id. at 84 . Under $\$ 2-302$, severability is expressly permitted and had the contract been severed in the Campbell case, neither party could have complained. While Campbell should not be permitted to enforce such a clause, the defendant should not be excused from performance when he is obviously in wilful breach of the main part of the agreement. 
It has been argued that Section 2-302 may permit spurious use of the unconscionability defense to obtain settlements in cases of wrongful breach. ${ }^{3 i}$ Application of the section will require considerable judicial knowledge of business practices, commercial negotiations, and marliet conditions. ${ }^{36}$ Litigation involving the complex evidence necessary to such knowledge may be lengthy, expensire, and uncertain, especially when directed to an issue so illdefined as unconscionability. Thus, the threat of invoking the section may be used. when a contract containing some questionable clauses has been breached, to bludgeon settlements from plaintiffs with valid claims.

The validity of this argument is, in part, dependent on who must bear the burden of proof under the section. If the plaintiff is required to disprove unconscionability, the position of captious defendants may indeed be strengthened. Unconscionability should. therefore, be riewed as an aftirmative defense. $^{3 \pi}$ If defendant fails to nake out a prima facie case, as might well be true in a "holdup" defense, a directed verdict for plaintiff would presumably" follow. If defendant succeeds in making out a case, there is no reason why the plaintiff should not be required to rebut it. Prospective defendants, knowing that they must substantiate their charges, may be more hesitant about invoking the section to coerce settlement.

Aside from the burden of proof, the argument that Section 2-302 will increase coerced settlements is of doubtful validity. The vagueness of the seetion presents no new problem to this area of the law. The term "unconscionability" has long been in use in equity ${ }^{38}$ and equally vague concepts have frequently plagued litigants at law..$^{39}$ Moreover, the section opens no evidentiary flood-gates since courts have traditionally permitted wide latitude in the introduction of evidence when the fairness of a contract is challenged."

35. See 18 L. of ChI. L. REv. 146, 152 (1950).

36. Ibid.

37. The Section makes no reference, either in text or comment, to the burden of proof. However, under a Miontana statute, similar to \$2-302 insofar as specific performance is concerned, it has been held that the burden of proof is on he who asserts any of the various defenses. Mont. Rev. Cone \$17-\$0\$ (1947), In re Grogan's Estate, 38 Mont. 540, 100 Pac 1044 (1909); Finlen v. Heinze, 28 Mont. 548, 73 Pac 123 (1903). Of course, it is incumbent on the plaintiff to show that the contract is fair on its face, but once he has established this, it is the defendant's job to prove that the cuntract is unfair by reason of extrinsic facts. Chicago Title \& Trust Co. v. Illinois Merchants' Trust Co., 329 Ill. 334, 160 N.E. 597 (1928); Indianapolis Nurthern Traction Co. v. Essington, 54 Ind. App. 286, 100 N.E. 765 (1913) ; Parsons v. Lipe, 158 Misc. 32, 286 X.Y. Supp. 60 (Sup. Ct 1933), aff'd sub nom. Parsons v. First Trust \& Deposit Co., 243 App. Div. 681,277 N.Y. Supp. 426 (4th Dep't 1935), aff'd, 269 N.Y. 630, 200 N.E. 31 (1936).

38. See note 1 supra.

39. See note 6 silpra. See also Llewellyn, Kerica of Prausnitz, The Slandardization of Commercial Contracts in English and Continental Lan; $52 \mathrm{H}$ 凡rv. L. REx. 700, 702 (1939).

40. See, e.g., Texas Co. v. Andres, 97 F. Supp. 454 (N.D. Idaho 1951); Fisk v. Fisk, 328 Mich. 570, 44 N.W 2d 184 (1950). Sec Denson v. MIapes, 71 F. Supp. 503, 508 (D. Nev. 1947), aff'd, 166 F.2d 322 (9th Cir. 1948). 
Section 2-302 simply accepts this principle ;1 it does not give unscrupulous defendants a more powerful weapon than they already possess.

By its vagueness the section does, however, pose a serious problem for the businessman, since the term "unconscionability" gives little guidance to the enforceability of a contract. This difficulty is increased by the obvious lack of judicial interpretation of the section. The framers apparently intended that traditional equity notions of fairness, developed in cases of specific performance, should control.22 Courts should look to these decisions for a guide in determining enforceability. Similarly, the drafter of contracts, who is concerned lest he run afoul of the section, should look to specific performance cases as the best available guide to the enforceability of his contract terms. ${ }^{43}$

Despite the possible difficulties which Section 2-302 may initially cause and the slight danger of increased "holdup" defenses, the protection which it will afford to parties with little bargaining power makes its enactment desirable. ${ }^{44}$ Traditional legal doctrines of fraud, mutuality, and ambiguity do not properly achieve this objective. Their use in negating contracts creates no standards by which the fairness of future contracts may be judged, and their failure to meet squarely the issue of fairness encourages defeated drafters to persist

41. "Sub-section (2) makes it clear that it is proper for the court to hear evidence upon these questions." UCC $\$ 2-302$, Comment (Official Draft, 1952).

42. This is the only logical inference since the unconscionability concept was of use almost exclusively in actions for specific performance. Sec note 1 supra. See also UCC $\$ 2-302$, Comment (Tentative Draft, 1949) wherein the drafters stated that the section was intended to "apply to the Field of Sales the equity courts' ancient policy of policing contracts for unconscionability or unreasonableness."

43. Of course these cases vary widely depending on the particular facts of each. Sce note 2 supra. Certain broad requirements have been enunciated such as: there may be no sharp and unscrupulous practices, no overreaching and no concealment of material facts. POAEROY, op. cit. supra note $1, \S 40$. The following cases illustrate some clauses which have been held unenforceable either by equity courts using the unconscionability doctrince or courts of law using one of the other concepts. Hume v. United States, 132 U.S. 406 (1889) (clause which set price forty times higher than current market price); Texas Co. v. Andres, 97 F. Supp. 454 (D. Idaho 1951) (an option to purchase clause where its import was not fully disclosed to the lessor); Weil v. Chicago Pneumatic Tool Co., 138 Ark. 534, 212 S.W. 313 (1919) (contract exempting seller from liability for any "loss of profit or damages from its failure to deliver goods ordered or for cancellation of this agreement."); New Prague Flouring Mill Co. v. Spears, 194 Iowa 417, 189 N.W. 815 (1922) (clause permitting seller to extend shipping date when such clatse was wrongfully used by seller to increase damages based on rising market price after the buyer had clearly breached); Meyer v. Packard Cleveland Motor Co., 106 Ohio St. 328, 140 N.E. 118, (1922) (clause providing that there were no warranties, express or implied, unless specifically set out in the agreement); Austin Co. v. Tillman Co., 104 Ore. 541, 209 Pac. 131 (1922) (clause limiting buyer's right to return goods held applicable only if seller had delivered goods which reasonably met the contract description). See also PAGE, op. cit. supra note $2, \S 641$.

44. Section 2-302 was enacted as a part of the Code in Pennsylvania. \$2-302 Act No. 1, Pennsylvania General Assembly, (1953). 
in imposing unfair terms. ${ }^{45}$ Moreover, extension of these doctrines to deal with an unconscionable contract establishes embarrassing precedents for their normal application. ${ }^{40}$ Section 2-302 eliminates these difficulties. Courts, in applying the section to unconscionable and non-separable contracts, should deny relief even though this is tantamount to cancellation. But when the unconscionable clause arises in a separable contract and does not invalidate the entire agreement, only that clause should be stricken. If applied in this manner, the section will be a significant contribution to sales law, and, even more important. to the whole area of contract law. ${ }^{4 \pi}$

45. See, Clark. J., concurring in Gaunt v. John Hancock Mut. Life Ins. Co, 160 F.2d 599, 603 (2d Cir. 1947).

46. See Llewellyn, Revica of Pratsnitz, The Standardization of Comuncrial contracts in English and Continental Lai,, 52 HaRs. L. REv. 700, 703 (1939). For an argument that the legal doctrines should be extended making the enactment of $\$ 2-302$ unnecessary see 18 U. of CHI. L. RET. 146, 152 (1950).

47. Section 2-302 "takes an important step in closing the cultural lag between legopolitical theory of the role of contract and the inflexibility of mass transactions conducted through limitedly authorized personnel in the hierarchies of commercial enterprise." Latty, Sales and Title in The Pruposed Code, 16 L.wW \& Contesp. Yroв. 3, 19 n.78 (1951). 